\title{
Pengenalan Analisis Statistika untuk Meningkatkan Penelitian dan Publikasi Fungsional Statistisi di Jawa Timur
}

\author{
Kartika Fithriasari $^{1, *}$ | Nur Iriawan ${ }^{1}$ | Adatul Mukarromah ${ }^{1}$ | Irhamah $^{1}$ | Heri Kuswanto ${ }^{1}$ | Wiwiek \\ Setya Winahju ${ }^{1}$ । Ulfa Siti Nuraini ${ }^{1}$
}

${ }^{1}$ Departemen Statistika, Institut Teknologi Sepuluh Nopember,Surabaya, Indonesia

\section{Korespondensi}

*Kartika Fithriasari, Departemen Statistika, Institut Teknologi Sepuluh Nopember, Surabaya, Indonesia. Alamat e-mail: kartika_f@statistika.its.ac.id

\section{Alamat}

Laboratorium Statistika Komputasi, Departemen Statistika, Institut Teknologi Sepuluh Nopember, Surabaya, Indonesia

\begin{abstract}
Abstrak
Jabatan fungsional statistisi memiliki tugas utama yaitu melakukan kegiatan statistik. Kegiatan statistik ini termasuk penyediaan data dan informasi statistik serta analisis dan pengembangan statistik. Jabatan fungsional statistisi dalam menjalankan tugasnya, perlunya peningkatan kemampuan dengan mengikuti pelatihan di bidang statistika. Pelatihan ini juga perlu keluaran yang sesuai dengan yang dibutuhkan fungsional statistisi. Oleh karena itu, pengabdian ini bertujuan untuk membantu meningkatkan kompetensi fungsional statistisi pada berbagai instansi di Jawa Timur dalam mengolah data dan publikasi, diharapkan dengan adanya pelatihan ini bisa meningkatkan kebergunaan informasi yang diperoleh agar dapat tersalurkan dengan baik. Materi yang disampaikan yaitu Statistika Data Driven, Visual dan Analisis Data, serta Karya Ilmiah dan Publikasi. Setelah adanya pelatihan, dilanjutkan dengan pendampingan terhadap fungsional statistisi dalam pengolahan data dan pembuatan karya ilmiah yang disusun oleh fungsional statistisi. Selain itu, manfaat yang dapat diperoleh yaitu terjalinnya kerja sama yang baik antara fungsional statistisi di Jawa Timur dan Departemen Statistika di Institut Teknologi Sepuluh Nopember.
\end{abstract}

Kata Kunci:

Analisis Data, Data Driven, Fungsional Statistisi, Jawa Timur, Karya Ilmiah dan Publikasi..

\section{1 | PENDAHULUAN}

\section{1 | Latar Belakang}

Jabatan fungsional statistisi merupakan jabatan bagi Pegawai Negeri Sipil (PNS) yang memiliki tugas utama untuk melakukan kegiatan statistik. Kegiatan statistik ini termasuk penyediaan data dan informasi statistik serta analisis dan pengembangan statistik. 
Salah satu tugas fungsional statistisi adalah memberikan informasi statistik berdasarkan data yang sudah dikumpulkan. Kemampuan penyajian data, ketepatan dalam menggunakan metode, dan pembuatan tulisan ilmiah sangat diperlukan untuk fungsional statistisi agar data mudah dipahami masyarakat, dapat melakukan perencanaan yang diperlukan oleh instansi terkait, dan sebagai jalan dalam meningkatkan jenjang jabatan dan karir bagi PNS.

Fungsional statistisi memerlukan suatu pelatihan untuk meningkatkan kemampuan dalam memberikan informasi kepada masyarakat. Fungsional statistisi juga memerlukan pengembangan keilmuan untuk memenuhi angka kredit yang sudah ditetapkan sehingga bisa dipergunakan untuk meningkatkan jenjang jabatannya.

Departemen Statistika merupakan salah satu Departemen di Institut Teknologi Sepuluh Nopember (ITS) yang memiliki tanggung jawab untuk menyebarkan ilmu statistika pada masyarakat. ITS sudah mempunyai MOU dengan Gubernur Jawa Timur sebagai pimpinan tertinggi di Provinsi Jawa Timur. Kerjasama ini dapat berupa pemberian pelatihan ke fungsional statistika di Organisasi Perangkat Daerah di Provinsi Jawa Timur. Kerjasama ini bertujuan untuk meningkatkan kemampuan fungsional statistisi dalam menjalankan tugas dan tanggung jawabnya.

Peningkatan kemampuan fungsional statistisi dapat dilakukan dengan mengikuti pelatihan di bidang statistika. Mengingat Departemen Statistika memiliki dosen dengan kompetensi baik di bidang statistika yang didukung dengan penelitian yang dilakukan untuk pengembangan metode maupun bahan ajar untuk proses pembelajaran. Dosen Statistika juga memiliki kompetensi untuk membuat karya ilmiah sebagai wadah untuk publikasi hasil penelitian.

Berdasarkan uraian tersebut tujuan dari pengabdian ini meningkatkan kompetensi fungsional statistisi dengan mengadakan pelatihan analisis data sehingga dapat mendukung program satu data Indonesia. Kerjasama antara Departemen Statistika dengan pemerintah daerah Jawa Timur akan tetap terjalin dengan pengaadaan pelatihan bagi fungsional statistisi. Departemen Statistika juga bisa menyediakan dosen-dosen yang ahli dibidang statistika untuk membagikan ilmu yang dimiliki. Pelatihan bagi fungsional statistika juga dilakukan dengan implementasi langsung terhadap permasalahan data statistik yang dimiliki oleh fungsional statistisi di dinas unit kerja sehingga peningkatan kompetensi bisa terwujud.

\section{2 | Perumusan Konsep dan Strategi}

Pentingnya meningkatkan kompetensi bagi fungsional statistisi membuat Departemen Statistika yang memiliki dosen ahli dibidangnya memiliki tanggung jawab untuk memberikan ilmu yang dimiliki. Peningkatan kompetensi ini sejalan dengan tugas dan wewenah fungsional statistisi dalam melakukan kegiatan statistik untuk mewujudkan satu data Indonesia. Kegiatan yang dilakukan oleh Departemen Statistika dalam meningkatkan kompetensi fungsional statistika adalah sebagai berikut:

1. Mengadakan pelatihan integrasi dan analisis data bagi perangkat daerah di Provinsi Jawa Timur. Pelatihan akan dilaksanakan secara interaktif dan diimplementasikan secara langsung terkait dengan unit kerja fungsional statistisi sehingga data yang tersedia pada setiap dinas dapat memberikan informasi yang dengan mudah dipahami oleh masyarakat. Materi yang diberikan meliputi: integrasi, analisis data dan membuat publikasi.

2. Selanjutnya dilakukan pembimbingan untuk mengolah data dan publikasi. Setiap peserta diberi 2 pembimbing untuk mengolah data dan selanjutnya melakukan publikasi bersama.

\section{2 | TUJUAN, MANFAAT, DAN DAMPAK KEGIATAN YANG DIHARAPKAN}

\section{1 | Tujuan}

Pengabdian ini bertujuan untuk membantu meningkatkan kompetensi fungsional statistisi dalam mengolah data dan publikasi. Jika kompetensi fungsional statistisi meningkat, maka informasi yang mereka hasilkan juga akan lebih baik.

\section{2 | Manfaat}

Manfaat dari pengabdian ini adalah bertambahnya pengetahuan mengenai kondisi data dan informasi di dinas/instansi pemerintah. Data atau kasus yang digunakan pada kegiatan ini, dapat dijadikan studi kasus dalam proses belajar mengajar. 


\section{3 | Dampak}

Dampak yang diharapkan dari kegiatan ini adalah akan memberikan manfaat bagi departemen atau laboratorium, seperti misalnya penelitian bersama, magang, Kerja Praktik dan Tugas Akhir.

\section{4 | Target Luaran}

Target luaran dari pengabdian ini adalah:

1. Menghasilkan peningkatan kompetensi fungsional statistisi perangkat daerah di wilayah Jawa Timur.

2. Meningkatkan kuantitas publikasi fungsional statistisi.

3. Beberapa materi dan hasil kajian dari studi kasus akan menambah kompetensi dalam mengolah data dan menghasilkan paper yang akan dipublikasiakan pada jurnal nasional.

4. Publikasi jurnal pengabdian masyarakat pada akhir kegiatan pengabdian masyarakat pada posisi submit.

\section{3 | TINJAUAN PUSTAKA}

\section{1 | Fungsional Statistisi}

Berdasarkan Peraturan Menteri Pendayagunaan Aparatur Negara dan Reformasi Birokrasi Republik Indonesia no 19 tahun 2013 tentang Jabatan Fungsional Statistisi dan Angka Kreditnya, definisi dari Jabatan Fungsional Statistisi adalah jabatan yang mempunyai ruang lingkup, tugas, tanggungjawab, dan wewenang untuk melakukan kegiatan statistik. Kegiatan ini mencakup penyediaan data dan informasi statistik, serta analisis dan pengembangan statistik. Terdapat unsur dan sub unsur kegiatan Statistisi, terdiri dari:

1. Pendidikan meliputi pendidikan sekolah dan memperoleh ijazah/gelar; pendidikan dan pelatihan fungsional di bidang statistik serta memperoleh Surat Tanda Tamat Pendidikan dan Pelatihan (STTPP) atau sertifikat; dan Pendidikan dan Pelatihan Prajabatan.

2. Penyediaan data dan informasi statistik, meliputi: persiapan; pengumpulan data; pengolahan; dan penyajian dan publikasi.

3. Analisis dan pengembangan statistik

4. Pengembangan profesi, meliputi: pembuatan karya tulis / karya ilmiah di bidang statistik; penyusunan petunjuk teknis pelaksanaan pengelolaan kegiatan statistik; dan penerjemahan / penyaduran buku atau karya ilmiah di bidang statistik.

5. Penunjang tugas statistisi, meliputi: pembimbing penuh kader Statistisi; pengajar/pelatih di bidang statistik; peran serta dalam seminar/lokakarya/ konferensi; keanggotaan dalam Tim Penilai Jabatan Fungsional Statistisi; keanggotaan dalam organisasi profesi Statistisi; perolehan penghargaan/tanda jasa/tanda kehormatan/satyalancana karya satya; dan perolehan ijazah/ gelar kesarjanaan lainnya.

Jabatan fungsional statistisi terdiri dari Statistisi Terampil dan Statistisi Ahli. Instansi Pembina jabatan fungsional statistisi adalah Badan Pusat Statistika (BPS).

\section{2 | Statistika}

Statistika adalah ilmu yang mempelajari tentang perencanaan, pengumpulan, analisis, interpretasi, hingga dapat memberikan kesimpulan dan saran. Statistika terdiri dari statistika deskriptif dan inferensia. Statistika deskriptif adalah metode-metode yang berkaitan dengan pengumpulan dan penyajian suatu gugus data sehingga memberikan informasi yang berguna, sedangkan statistika inferensia lebih pada menganalisa dan menginterpretasikannya sehingga akan didapatkan kesimpulan dan saran [1].

Data terbagi menjadi 2 hal yaitu data kategorik dan data kontinyu. Dalam suatu data, hal yang perlu diperhatikan yaitu skala pengukuran data. Terdapat 4 skala pengukuran data, yaitu: 
1. Nominal, dimana objek-objek pengamatannya dibagi menjadi kelompok yang berbeda, contoh: jenis kelamin.

2. Ordinal, dimana datanya berupa pengamatan yang berbeda berdasarkan urutan tertentu, contoh: tingkat Pendidikan.

3. Interval, dimana data berupa jarak antara dua titik yang bersifat kontinyu, contoh: suhu.

4. Ratio, dimana data yang memiliki sifat bisa dibandingkan, contoh: berat badan.

\section{3 | Visualisasi Data}

Visualisasi data lebih pada bentuk penyajian data agar lebih mudah dalam memahami karakteristik dalam suatu data. Penyajian data dalam statistika deskriptif kerap digambarkan dalam bentuk tabel maupun diagram. Dalam Kamus Besar Bahasa Indonesia, diagram merupakan gambaran untuk memperlihatkan atau menerangkan sesuatu. Dimana dalam statistika, sesuatu berarti sebuah data yang ingin diketahui karakteristiknya. Beberapa diagram antara lain sebagai berikut.

1. Diagram Batang

Diagram ini digunakan untuk menggambarkan data diskrit atau kategorik. Diagram ini terukur kuantitas dari suatu kategorinya berdasarkan tinggi batangnya. Terdapat dua jenis penyajian dengan diagram batang yaitu secara horizontal dan vertikal $^{[2]}$. Contoh diagram batang hasil analisis fungsional statistisi di dinas koperasi tergambar pada Gambar 1.

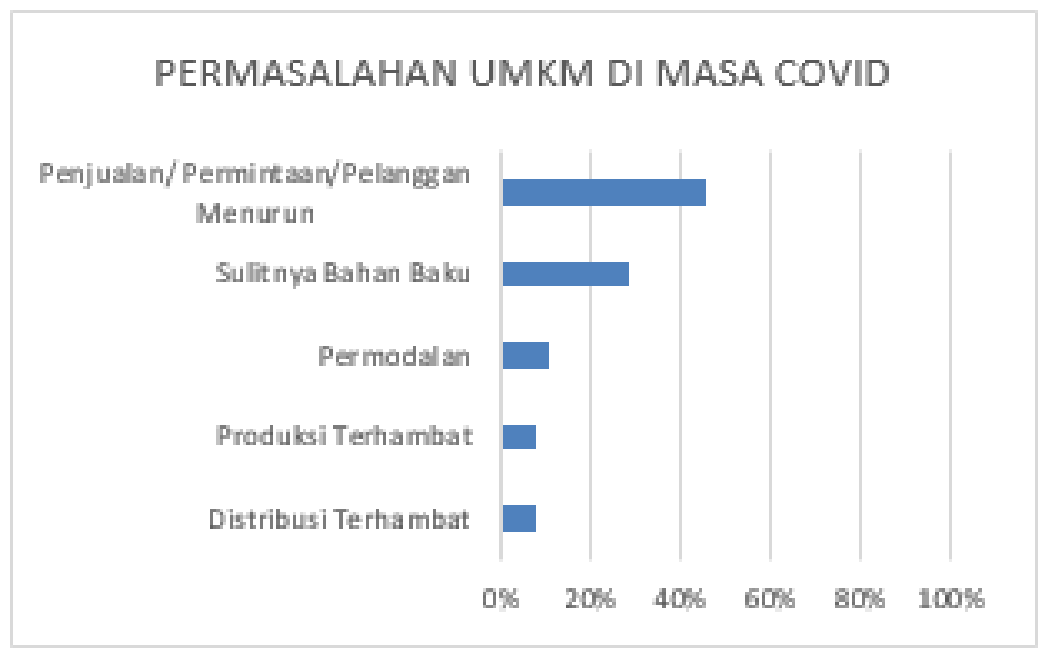

Gambar 1 Diagram Batang

\section{Diagram Lingkaran}

Diagram ini merupakan diagram dengan bentuk penyajian datanya berbentuk lingkaran yang dibagi menjadi beberapa juring lingkaran. Diagram ini menentukan perbandingan dengan menentukan besarnya sudut lingkaran. Diagram lingkaran biasanya digunakan untuk mengetahui perbandingan data terhadap keseluruhan data ${ }^{[2]}$. Contoh diagram lingkaran hasil analisis fungsional statistisi di dinas koperasi terdapat pada Gambar 2.

\section{4 | Machine Learning}

Analisis data digunakan untuk mendapatkan suatu model yang dapat menginterpretasikan suatu data. Data yang sudah dianalisis akan mendapatkan kesimpulan yang bisa digunakan sebagai saran untuk keputusan selanjutnya.

Salah satu metode analisis data yang digunakan adalah machine learning. Secara umum, machine learning terbagi menjadi dua hal berbeda, yaitu supervised dan unsupervised. Kedua hal tersebut dibedakan pada ada tidaknya respon atau label atau target 


\section{PERMINTAAN PASAR (UMKM) \\ SETELAH COVID}

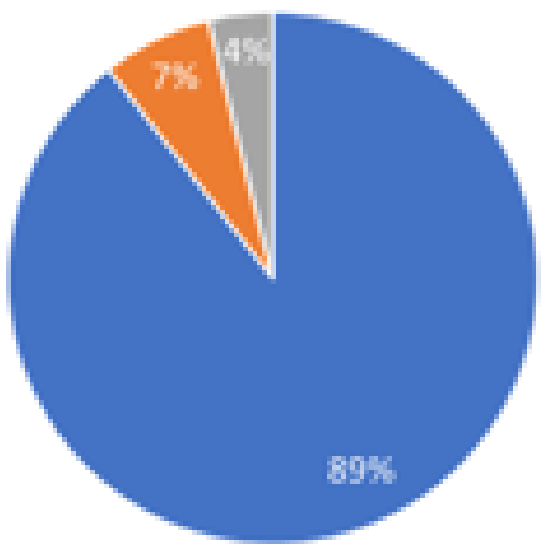

Menurum

Tetap

Melonjak:

Gambar 2 Diagram Lingkaran

pada data yang akan dilakukan analisis. Supervised terdiri dari klasifikasi dan regresi, dimana klasifikasi digunakan pada targettarget yang bersifat kategorik, sedangkan regresi merupakan target-target bersifat kontinyu. Untuk unsupervised bagi data yang tidak memiliki target, metode yang digunakan yaitu clustering. Metode yang digunakan bisa berupa k-Means dan hirarki ${ }^{3}$.

Analisis data kerap berkaitan langsung dengan software. Software yang digunakan bisa bermacam-macam bergantung pada compatible atau tidaknya dalam menganalisis suatu data dengan metode tertentu. Software yang digunakan bisa berupa Microsoft Excel, SPSS, Minitab, R, Python, SAS, dan lain-lain.

\section{4 | STRATEGI, RENCANA KEGIATAN DAN KEBERLANJUTAN}

Kegiatan ini merupakan program pengabdian masyarakat yang dilakukan untuk menjawab permasalahan yang telah diuraikan pada subbab latar belakang. Diharapkan dengan kegiatan pengabdian ini, fungsional statistisi dapat memiliki pengetahuan tambahan mengenai kondisi data/informasi pada dinas atau pemerintahan, sehingga akan menambahkan publikasi dari olahan data tersebut.

Workshop ini melibatkan para ahli dalam bidangnya, mengingat terlibatnya para dosen Statistika ITS yang telah menguasai ilmu statistika sehingga diharapkan dapat memberikan pengalaman terbaik bagi para peserta.

Dalam kegiatan ini, peran Departemen Statistika ITS adalah menyiapkan materi pelatihan dan tenaga pengajar, serta melaksanakan belajar mengajar saat pelatihan dan pendampingan. Sebelum diadakannya kegiatan tentunya ada persiapan yang matang meliputi penyusunan jadwal pelatihan, persiapan materi, serta koordinasi waktu pelaksanaan pelatihan, serta penginfoan pada fungsional statistisi terhadap waktu dan acara pelatihan. Kegiatan pengabdian ini terbagi menjadi 2 bagian, yaitu pelatihan dan pendampingan.

1. Pelatihan

Pada saat pelaksanaan kegiatan, pelatihan dilakukan dengan:

- Pemberian materi

Penjelasan singkat akan materi-materi yang telah disiapkan oleh tenaga pengajar Departemen Statistika ITS, dimulai dari teori data driven hingga publikasi. 
- Diskusi Interaktif

Diskusi ini berkaitan tentang tanya jawab tentang materi yang telah dijelaskan sebelumnya, dan peserta diberi kesempatan untuk mendiskusikan hal-hal terkait publikasi.

2. Pendampingan

Setelah dilakukan pelatihan, kegiatan ini dilanjutkan dengan pendampingan. Peserta diberi kesempatan berdiskusi dengan tim abdimas untuk melakukan analisis data lebih lanjut dan penyusunan publikasi. Proses pendampingan ini dilakukan secara daring. Proses ini diberikan agar fungsional statistisi dapat melakukan publikasi di jurnal bereputasi.

3. Keberlanjutan

Keberlanjutan dari kegiatan ini tentu sangat diharapkan. Materi pelatihan dapat dilakukan sebagai acuan untuk pembuatan artikel yang bisa dipublikasikan di jurnal bereputasi lainnya. Pengabdian masyarakat ini tidak menutup kemungkinan untuk dilakukan pada daerah atau provinsi lainnya, mengingat fungsional statistisi sangat membutuhkan analisis statistika yang lebih tinggi untuk kemampuan mereka.

\section{5 | HASIL YANG DICAPAI}

Hasil pengabdian ini terdiri atas dua hal utama yaitu pelatihan dan pendampingan penyusunan artikel ilmiah bagi para fungsional statistisi.

\section{1 | Pelatihan Workshop}

Pelatihan telah dilaksanakan secara daring pada hari Sabtu tanggal 19 September 2020. Peserta pelatihan berjumlah 29 fungsional statistisi dari dinas atau instansi di Jawa Timur. Pelatihan ini memuat materi tentang:

- Statistika Data Driven

Materi ini memuat tentang penganalisisan data yang bergantung pada data yang didapatkan ${ }^{[4}$. Metode yang digunakan dipilih berdasarkan tujuan dan variabel serta karakteristik data yang dimiliki.

- Visualisasi dan Analisis Data

Materi ini berfokus pada cara menvisualisasikan data yang tepat untuk mendapatkan karakteristik data yang dapat menginfokan data tersebut ${ }^{[5]}$. Selain itu, materi ini juga tentang pemilihan metode yang tepat digunakan pada data-data serta tujuan yang dimiliki, sehingga akan mendapatkan kesimpulan dan keputusan yang baik.

- Pengantar RShiny

Materi ini tentang pengenalan pembuatan dashboard dengan suatu software open-source R dengan menggunakan library Shiny 6 .

- Bagaimana Cara Membuat Artikel Ilmiah

Materi ini berfokus pada bagaimana menulis artikel yang baik, dimulai dari penamaan judul hingga pengecekan plagiat ${ }^{[7}$.

- Penulisan Ilmiah pada Jurnal Nasional

Materi ini diberikan sebagai pengetahuan tentang proses publikasi jurnal, jurnal terindeks scopus, hingga tempat atau website yang baik untuk jurnal yang akan dipublikasikan.

Materi-materi tersebut diberikan pada fungsional statistisi sebagai referensi dalam pembuatan artikel ilmiah. Tabel 1 merupakan salah satu dokumentasi dari masing-masing materi. Setelah dilakukannya pemberian materi maka dilanjutkan dengan sesi tanya jawab atau sesi diskusi antara fungsional statistisi dengan dosen di Departemen Statistika. Dokumentasi kegiatan pelatihan ini terlihat pada Gambar 3.

\section{2 | Pendampingan Penyusunan Artikel Ilmiah}

Dalam penyusunan artikel ilmiah, dilakukan pendampingan oleh Dosen Statistika terhadap fungsional statistisi di Jawa Timur. Pendampingan ini menghasilkan sebuah draft artikel untuk dipublikasikan pada jurnal nasional. 
Tabel 1. Halaman Pertama Setiap Materi

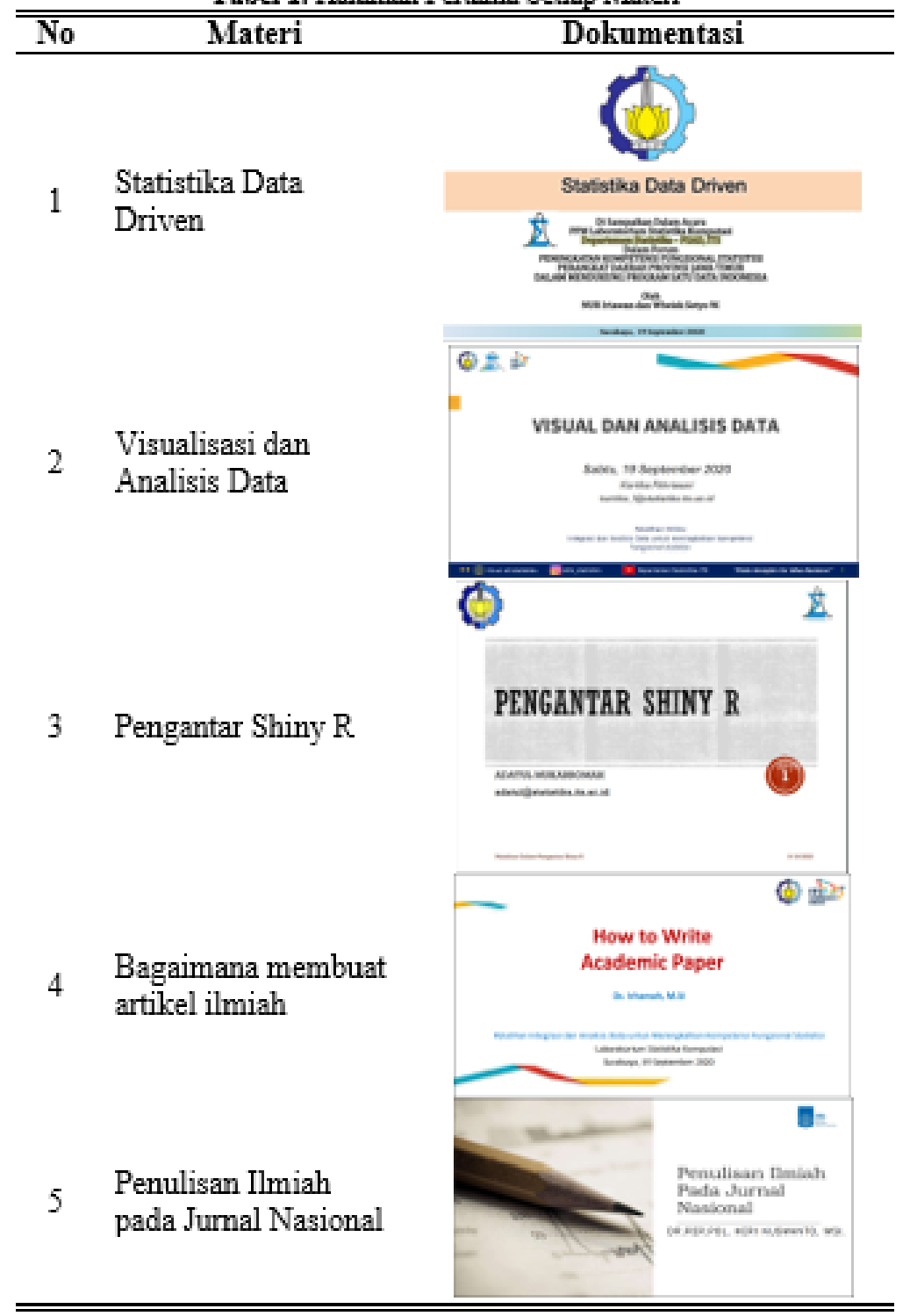

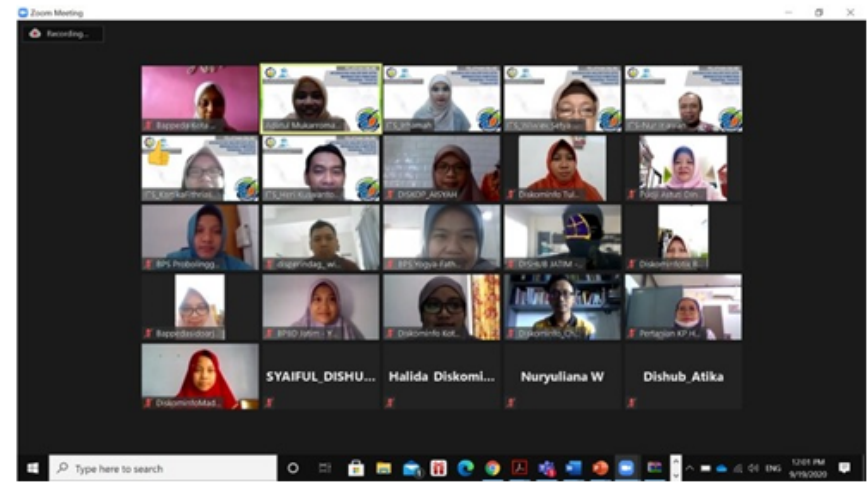

Gambar 3 Pemateri dan Peserta pada saat Pelatihan 


\section{3 | Analisis Capaian terhadap Target Luaran}

Luaran dari pengabdian ini berupa peningkatan pemahaman fungsional statistisi terhadap analisis metode Statistika yang digunakan untuk publikasi artikel ilmiah. Peserta pelatihan merasa mendapatkan manfaat serta tambahan wawasan dan pengetahuan. Hal ini diketahui dari $80 \%$ dari jumlah pesserta menyatakan ingin melanjutkan pendampingan untuk membuat publikasi dengan tim Departemen Statistika ITS. Selain itu, proses pelatihan yang terdokumentasi berupa video yang bisa dilihat Kembali untuk membantu dalam pembuatan artikel publikasi. Materi selama pelatihan juga telah diberikan saat pelatihan untuk menjadi acuan dalam penyusunan paper penelitian. Dalam kegiatan ini juga menghasilkan sebuah draft artikel untuk dipublikasikan dalam jurnal nasional. Terakhir juga telah dilaksanakan publikasi jurnal pengabdian masyarakat pada akhir kegiatan pada posisi submit.

\section{4 | Kendala}

Terdapat beberapa kendala yang terjadi selama proses pendampingan, diantaranya waktu kesibukan peserta mengingat jam kerja yang relatif padat. Hal ini berdampak pada analisis data dan pembuatan karya ilmiah untuk publikasi yang kurang cepat. Sehingga solusi dari kendala ini adalah meningkatkan komunikasi via sosial media antara fungsional statistisi dan Dosen Departemen Statistika ITS agar pendampingan tetap terjaga dengan baik.

\section{6 | KESIMPULAN DAN SARAN}

Kesimpulan dari kegiatan ini adalah bahwa pelatihan telah diselenggarakan secara daring pada tanggal 19 September 2020. Pelatihan ini dilanjutkan dengan pendampingan oleh Departemen Statistika pada fungsional statistisi di Jawa Timur. Kegiatan ini menghasilkan satu draft artikel untuk disubmit ke jurnal nasional. Peserta juga merasa mendapatkan manfaat, dan tambahan wawasan dan pengetahuan akan terselenggaranya kegiatan ini.

Saran berdasarkan hasil kegiatan ini adalah fungsional statistisi hendaknya secara berkala melakukan analisis data di perangkat daerah masing-masing. Hasil analisis selanjutnya disajikan dalam bentuk karya ilmiah serta dipublikasikan. Hal ini dilakukan untuk meningkatkan kemampuan analisis dan publikasi.

\section{7 | RENCANA SELANJUTNYA}

Pada kegiatan ini materi metode Statistika yang digunakan yaitu metode dasar. Untuk selanjutnya, diharapkan dapat memberikan pelatihan yang mengarah pada kedalaman materi pada analisis big data. Materi ini sangat dibutuhkan mengingat data-data yang diperoleh pada era ini adalah data-data yang relatif kompleks sehingga kemampuan fungsional statistisi akan lebih baik. Selain itu, pengabdian masyarakat ini bisa dilakukan keberlanjutan di daerah atau provinsi yang lain, karena materi ini merupakan peningkatan kemampuan yang baik bagi tugas utama untuk fungsional statistisi.

\section{8 | UCAPAN TERIMA KASIH}

Terima Kasih disampaikan kepada Institut Teknologi Sepuluh Nopember, Lembaga Penelitian dan Pengabdian Masyarakat ITS serta Departemen Statistika ITS atas dana yang telah diberikan untuk kegiatan pengabdian ini sesuai surat perjanjian pelaksanaan pengabdian masyarakat No: 1771/PKS/ITS/2020. Terima kasih juga disampaikan kepada para fungsional statistisi dari dinas/instansi Jawa Timur sebagai Mitra Pengabdian sehingga kegiatan ini dapat terselenggara dan terselesaikan dengan baik.

\section{Referensi}

1. Walpole R. Introduction to Statistics Macmillan. New York 1974;340.

2. Streit M, Gehlenborg N. Bar charts and box plots: creating a simple yet effective plot requires an understanding of data and tasks. Nature methods 2014;11(2):117-118. 
3. Alloghani M, Al-Jumeily D, Mustafina J, Hussain A, Aljaaf AJ. A systematic review on supervised and unsupervised machine learning algorithms for data science. Supervised and unsupervised learning for data science 2020;p. 3-21.

4. Iriawan N, Pemodelan dan Analisis Data-Driven. ITS Press, Surabaya; 2012.

5. Soukup T, Davidson I. Visual data mining: Techniques and tools for data visualization and mining. John Wiley \& Sons; 2002.

6. Beeley C. Web application development with R using Shiny. Packt Publishing Ltd; 2013.

7. Belcher WL. Writing your journal article in twelve weeks: A guide to academic publishing success. University of Chicago Press; 2019.

Cara mengutip artikel ini: Kartika Fithriasari Nur Iriawan Adatul Mukarromah Irhamah Heri Kuswanto Wiwiek Setya Winahju Ulfa Siti Nuraini, (2021), Pengenalan Analisis Statistika untuk Meningkatkan Penelitian dan Publikasi Fungsional Statistisi di Jawa Timur, Sewagati: Jurnal Pengabdian Kepada Masyarakat, 5(3):326-334. 